\title{
Stem-cell 'heroes' celebrate a series of breakthroughs
}

\section{SAN FRANCISCO}

For years, dark clouds of controversy have obscured the horizons of stem-cell research. But at last month's annual meeting of the International Society for Stem Cell Research, scientists were buzzing with optimism.

"The tide is turning," said Len Zon, the society's outgoing president, at the meeting's opening session in San Francisco. "The field looks very bright."

Zon and the 2,100 other attendees have plenty to celebrate. One chamber of the US Congress has voted to ease restrictions on federal funding for stem-cell research, and the Senate may take up the issue this month. The creation of state stem-cell research initiatives - including the \$3-billion

"We must work quickly, or the forces against us may reverse the tide." with an adult skin cell and that the stem cell 'reprogrammed' the skin cell's nucleus, causing it to act like an embryonic stem cell. He still has to work out how to remove the stem-cell DNA from the fused cell. But if he can, the technique could be a way to produce new stem-cell lines matched to the DNA of a patient, without having to use a donor egg or create an embryo the two sources of most of the ethical concerns surrounding embryonic stem-cell research.

Meanwhile, pioneering stem-cell biologist James Thomson of the University of Wisconsin-

Madison reported progress in making stem-cell lines free of contamination by contact with material from other animals. This is crucial for making lines suitable for use as treatments in people. All cell lines currently available under US federal funding restrictions are contaminated in this way, so Thomson says that he hopes the research will help push the United States to change its rules.

Some investigators cautioned patience. Lorraine Young of the University of Nottingham, $\mathrm{UK}$, unveiled the first complete profile of epigenetic modifications in human stem cells, and warned that cultured cell lines can change rapidly over time. This needs to be better understood before pressing ahead with clinical research, she said.

But CIRM chairman Robert Klein felt there was no time to lose. "You are my heroes," he told the meeting. "We must work quickly, or the forces against us may reverse the tide."

Erika Check vard Stem Cell Institute in Boston reported that his lab has fused a human embryonic stem cell
Clear thinking:

Robert Klein, chairman of the

California

Institute for

Regenerative

Medicine, puts his

mind to the

challenges ahead. 